\title{
Antigen Heterogeneity of Human B and T Lymphocytes
}

\author{
Enrique M. Rabelino, Howard M. Grey, Sandra LaForge, \\ Bernard Pirofsky, Noburu Kashiwagi, and Arthur Malley \\ From the Department of Medicine, Section of Allergy and Clinical Immunology, \\ National Jewish Hospital and Research Center, Denver, Colorado 80206, the \\ University of Oregon Medical School, Portland, Oregon 97201, the Veterans \\ Administration Hospital, Denver, Colorado 80220, and the Oregon Regional \\ Primate Research Center, Beaverton, Oregon 97005
}

\begin{abstract}
A B S T RACT Rhesus monkeys were immunized with normal human lymphoid cells, cultured lymphoid cells, and chronic leukemic lymphocytes. Antisera were analyzed by cytotoxicity and immunofluorescence techniques to study the antigenic characteristics of human lymphocytes.

In an attempt to obtain a reagent specifically reactive with $\mathrm{T}$ (thymus-derived) lymphocytes, an antispleen antiserum was absorbed with cells from five B- (bone marrow-derived) cell lines. After absorption, the antiserum killed $60-75 \%$ of peripheral blood lymphocytes and $40-50 \%$ of tonsil cells, so that there was a relationship between the percentage of killed cells and the proportion of $\mathrm{T}$ lymphocytes. However, when cells after cytotoxic treatment were assayed for rosette formation with sheep erythrocytes (a T-cell marker) $5-20 \%$ of viable rosette-forming lymphocytes were found. Therefore, this antiserum was cytotoxic for only $75-90 \%$ of $T$ cells.
\end{abstract}

From studies performed with antisera prepared against spleen and B-cell lines, we conclude that lymphoblastoid cells are antigenically different and deficient in comparison to normal B lymphocytes. In addition, cultured B-cell lines appear to be antigenically heterogeneous, as shown by the cytotoxic activity remaining in antispleen and anti-B-cell lines sera after absorption with various numbers and types of lymphoid cell lines. After absorption with normal lymphocytes, an antiserum produced against chronic lymphatic leukemia cells had specific activity associated with 12 chronic lymphatic leukemia cells tested. Absorption of the same antiserum with leukemic cells from two patients showed that a certain degree of antigenic heterogeneity also exists among chronic leukemic lymphocytes.

Dr. Rabellino's present address is The Swiss Institute for Experimental Cancer Research, 1011 Lausanne, Switzerland.

Received for publication 29 August 1975 and in revised form 20 October 1975.

\section{INTRODUCTION}

A number of publications in the last few years widely support the concept that there are two major populations of lymphocytes, one derived from thymus ( $\mathrm{T}$ cells) ${ }^{1}$ and the other from bone marrow (B cells) (1). To identify these two populations cell markers such as surfacebound immunoglobulin (2-4), receptor for third component of complement (C3 receptor) $(5,6)$, receptor for Fc fragment of $\operatorname{IgG}$ (Fc receptor) $(7,8)$, and membrane antigens (9-11) have been used, however, the reliability of some of these markers has recently come into question (12-15). Antigenic analysis is potentially useful for these purposes since it may be possible to detect a variety of surface components rather than single molecular types such as surface Ig. Distinct surface antigens have been demonstrated in lymphocyte populations by a variety of sensitive serological techniques such as cytotoxicity, immunofluorescence, immunoferritin, and mixed agglutination. In mice, for example, specific antigenic markers have been distinguished on the surface membranes of both $\mathrm{T}$ and $\mathrm{B}$ lymphocytes by either alloor hetero-antisera $(9-11,16,17)$. Thymus-specific antigens have also been detected on rabbit $T$ cells (18). In man, the recognition of antigenic determinants specifically associated with either T- or B-lymphocyte populations has met with only partial success $(19,20)$. It appears that antisera raised against fetal thymus (21),

1 Abbreviations used in this paper: B cells, bone marrowderived lymphocytes; C3 receptor, receptor for third component of complement; CRL, complement receptor lymphocyte; CLL, chronic lymphatic leukemia; E, sheep erythrocyte; EAC, erythrocyte-IgM antibody-complement complexes; ERFC, sheep erythrocyte rosette-forming cells; Fc receptor, receptor for Fc fragment of IgG; FCS, fetal calf serum; NHS, normal human serum; RhaNS, rhesus antinormal spleten antiserum; RhaBCL, rhesus antilymphoblastoid B-cell line antiserum; RhaCLL, rhesus antichronic lymphatic leukemia antiserum; $T$ cells, thymus-derived lymphocytes. 
emulsified cerebrum (22), and peripheral lymphocytes from agammaglobulinemic patients (23) retain some degree of $T$-cell specificity after absorption with chronic lymphatic leukemia lymphocytes (CLL) and lymphoblastoid cultured cells. Also, certain B-cellassociated activity has been detected in antisera raised against CLL cells and absorbed with thymus (24). However, it has been found difficult to standardize and make reproducible the production of such antisera. As a result of HL-A typing and antigenic studies on leukemia cells, quantitative and qualitative antigenic differences have been found between normal and leukemia lymphocytes. These differences have been defined as the absence of normal determinants or the existence of extra antigens on the surface of leukemic cells, not found on normal peripheral lymphocytes (25-34). Similarly, heterogeneity in surface antigens have also been observed in normal human lymphocytes under long-term culture conditions (35-36). Thus it is of interest to define further the antigenic heterogeneity of CLL cells and cultured lymphoid cells.

The present study was undertaken to characterize further the cell-surface antigens present on normal human lymphocytes, lymphocytes from patients with CLL and lymphoblastoid $B$ cells, using antisera raised in primates.

\section{METHODS}

Clinical material, cell separation. Peripheral blood lymphocytes from normal subjects, cord blood, blood from patients with chronic and acute lymphatic leukemia and agammaglobulinemia were separated by using a procedure combining sequentially, phagocytic loading with carbonyl iron particles, sedimentation in dextran, and centrifugation on Hypaque-Ficoll. Blood was collected in heparinized syringes $(2-5 \mathrm{U} / \mathrm{ml})$ and then mixed with $1 \%$ poly-L-lysinesensitized carbonyl iron suspension in Hank's balanced salt solution (HBSS) prewarmed to $37^{\circ} \mathrm{C}$ containing twice the regular amount of $\mathrm{CaCl}_{2}$ and $\mathrm{MgCl}_{2}$ and $3 \% \mathrm{~T} 250$ dextran, placed in a horizontal axial rotator, and rotated at $15 \mathrm{rpm}$ at $37^{\circ} \mathrm{C}$ for $50 \mathrm{~min}$. Erythrocytes and cells with ingested iron were then sedimented at room temperature for $60-90$ min. Finally, the leukocyte-rich supernate was diluted with 2 vol of saline, and each $20 \mathrm{ml}$ was layered onto $5 \mathrm{ml}$ of Hypaque-Ficoll $(d 1.077 \mathrm{~g} / \mathrm{ml}$ ) in siliconized $23 \times 105-\mathrm{mm}$ glass centrifuge tubes and centrifuged at $4^{\circ} \mathrm{C}, 500 \mathrm{~g}$, for $20 \mathrm{~min}$. Cells from the interface were harvested. This preparation contained $91-97 \%$ lymphocytes which were over $95 \%$ viable and represented $50-70 \%$ of the original blood lymphocyte population. Cells were washed three times in HBSS (without $\mathrm{Ca}^{++}$and $\mathrm{Mg}^{++}$) or saline before use. CLL blood was only processed with dextran sedimentation and $\mathrm{Hy}-$ paque-Ficoll since the leukocyte population contained more than $90 \%$ lymphocytes. The recovery obtained with CLL cells was at least $70 \%$ of the starting lymphoid population.

Cultured human lymphoid cells. Cultured lymphoblastoid cell lines were established at the Veterans Administration Hospital, Denver, from the buffy coat of six different normal blood donors. They are designated as shown in the tables, according to the initials of the donors from whom they were established. The cells were maintained in spinner culture at a concentration of $1-5 \times 10^{5} / \mathrm{ml}$ of RPMI 1640 containing $10 \%$ fetal calf serum (FCS), $2 \mathrm{mM}$ glutamine, $100 \mu \mathrm{g}$ streptomycin $/ \mathrm{ml}$, and $100 \mathrm{U}$ penicillin $/ \mathrm{ml}$ for long periods of time (months). Cultured cells for absorption and testing were obtained from the spinner flasks at the time of harvesting (biweekly) and washed in 40-50 vol of cold saline three times before use.

Antilymphocyte sera. Rhesus monkeys were immunized with human lymphocytes (normal spleen, cultured lymphoblastoid cells, and peripheral blood lymphocytes from one patient with CLL) by injecting $1-3 \times 10^{8}$ washed cells intramuscularly in complete Freund's adjuvant every 2 wk for a variable period of time $(2-10 \mathrm{mo})$. Immunizing cells were always obtained from the same source, either by periodic sampling or by using cells stored in liquid nitrogen. Serum samples were collected at different stages of immunization and stored at $-70^{\circ} \mathrm{C}$.

Heat inactivated $\left(56^{\circ} \mathrm{C}, 30 \mathrm{~min}\right)$ undiluted antisera from one or more bleeding samples were used for absorption. Even though none of the antilymphocyte sera showed detectable activity against normal human serum (NHS) by immunodiffusion, all were absorbed with $100 \mathrm{mg}$ of lyophilized whole NHS/ml. The antisera had some activity against human erythrocytes when tested by hemagglutination. One or two absorptions with one-fifth serum volume of packed AB-RH-positive erythrocyte stroma were necessary to absorb out all of the agglutinin activity. Absorption with cells were performed under constant mixing by using a horizontal axial rotator at $40 \mathrm{rpm}$, first for $1 \mathrm{~h}$ at room temperature and then $8-10 \mathrm{~h}$ at $4^{\circ} \mathrm{C}$. Human liver was used as a source of nonlymphoid absorbing cells. The viability of the cells used for absorption was in general over $80 \%$. The absorption procedure did not result in any major change in protein concentration in the antisera, as measured by nephelometry. The final absorptions involved varying amount of human lymphoid cells as detailed in Results.

Cytotoxicity assay. The antilymphocyte sera were assayed by cytotoxicity using both the dye uptake and ${ }^{51} \mathrm{Cr}$ release method. A slight modification of Wigzell's method of ${ }^{51} \mathrm{Cr}$ labeling was used (37). This consisted of labeling lymphocytes resuspended in $200 \mu 1$ of $5 \%$ FCS Tris buffer $\mathrm{pH}$ 7.2. The use of a reduced number of cells $\left(5-10 \times 10^{\circ}\right)$ in a smaller volume results in higher specific cell labeling and allows the use of only $1-4 \times 10^{4}$ target cells per assay. Equal volumes $(50 \mu \mathrm{l})$ of cells, antisera in serial dilutions, and undiluted normal rabbit serum (absorbed with $5 \times 10^{\circ}$ human leukocytes $/ \mathrm{ml}$ ) as the source of complement, were incubated for $1 \mathrm{~h}$ at $37^{\circ} \mathrm{C}$. After incubation with medium, complement or antiserum the mean spontaneous isotope release was $14 \%(\mathrm{SD}=2.8)$. Maximum variation in the ${ }^{\circ 1} \mathrm{Cr}$ release within duplicate or triplicate tests did not represent more than $2.7 \%$ of the total ${ }^{51} \mathrm{Cr}$ release (mean $=1.25$; $\mathrm{SD}=0.8)$. Specific ${ }^{51} \mathrm{Cr}$ release was estimated using the following formula: (Counts released with antiserumcounts released with normal serum)/(counts released with freeze thawed cells - counts released with normal serum or maximum counts released with antiserum) $\times 100$.

The dilution of an antiserum required for $50 \%{ }^{5} \mathrm{Cr}$ release was used as an end point. When the dye exclusion method was used, the assay was set up similarly and either $0.1 \%$ trypan blue or $0.5 \%$ eosin was used for microscope visualization.

Immunofuorescence. The antilymphocyte sera were also tested by indirect immunofluorescence using rabbit antirhesus gamma globulin conjugated with fluorescein isothiocyanate. Antiserum to rhesus gamma globulin was 
produced in rabbits which were rendered tolerant to human gamma globulin by injecting intravenously ultracentrifuged Cohn II fraction of human serum according to a method previously described (38). Although the rabbit anti-rhesus gamma globulin showed no cross-reactivity with human serum proteins by immunodiffusion, its IgG fraction was absorbed on a human gamma globulin-conjugated Sepharose 4B column. After this, the immunoabsorbed serum was fluoresceinated as described elsewhere (3), resulting in a fluorescein/protein molar ratio of $2.8 / 1$. Cells were stained by following the usual indirect technique, using as medium HBSS with $0.03 \mathrm{M}$ EDTA and $0.02 \%$ sodium azide throughout the procedure. Cells were examined in suspension with a Leitz ultraviolet microscope (E. Leitz, Inc., Rockleigh, N. J.) equipped with epi-illumination and phase contrast.

Detection of complement receptor lymphocytes ( $C R L)$, sheep erythrocyte rosette-forming cells (ERFC), and surface-bound immunoglobulin. The detection of CRL, ERFC, and surface-bound immunoglobulin was performed as previously described $(4,39-41)$. To enrich for $T$ cells, lymphocytes were rosetted with erythrocyte-IgM antibodycomplement complexes (EAC) under the same conditions as described before, but larger cell numbers were used. Tonsil lymphocytes $\left(50-100 \times 10^{8}\right)$ were incubated with EAC (25 EAC/lymphocyte) then resuspended in $20 \mathrm{ml}$ $15 \%$ FCS RPMI 1640, layered onto $5 \mathrm{ml}$ Hypaque-Ficoll $(1.077 \mathrm{~g} / \mathrm{ml})$, and centrifuged at $500 \mathrm{~g}$ for $20 \mathrm{~min}$ at $4^{\circ} \mathrm{C}$. Under these conditions, cells collected from the interface layer contained a higher proportion of ERFC ( $T$ cells) than the original cell preparation.

\section{RESULTS}

Antisera raised against normal lymphocytes. To obtain antihuman cell antisera with activity predominantly against normal lymphocytes, rhesus monkeys were immunized with normal spleen cells. A pool of bleedings collected from a single animal after 8-15 wk of immunization was studied. This rhesus anti-normal spleen antiserum (RhaNS) killed $50 \%$ of normal lymphocytes at dilution $1 / 300$ to $1 / 1,000$. This titer was reduced by only $15-20 \%$ after absorptions with normal human serum, red cells, and liver cells. In an attempt to make this antiserum specific for $T$ lymphocytes, aliquots of this antinormal spleen serum were absorbed with human cultured lymphoblastoid cells. Cultured cells from five different cell lines were chosen as absorbing B cells since over $95 \%$ of these cells carried one or both of the B-cell membrane markers, surface $\mathrm{Ig}$, and C3 receptor $(39,42)$. When $B$ cells from one cell line $(B j)$ were used to absorb RhaNS, $0.6 \times 10^{\circ}$ cells $/ \mathrm{ml}$ of serum were needed for an effective absorption. The effectiveness of the absorption was monitored by the loss of both cytotoxic reactivity and indirect immunofluorescent staining of absorbing cells. However, after this absorption, activity was still detected against $100 \%$ of normal peripheral lymphocytes, CLL cells, and other cultured B cells ( Table I). Therefore no indication of selective $\mathrm{T}$-cell killing was detected with this absorbed antiserum. In contrast to those results the same antiserum, RhaNS, when absorbed with a pool of five different cultured B cells, showed no reactivity against any cultured $\mathrm{B}$ cells or CLL cells tested (Table II). However, between $65-80 \%$ of the normal peripheral blood lymphocytes and $46 \%$ of a tonsil cell preparation were killed by the absorbed antiserum. Evidence that this partial killing was not due to the weakness of the antiserum was obtained by the dose-response experiment shown in Fig. 1. A clear plateau of activity against a proportion of lymphoid cells was obtained using the absorbed antiserum up to $1: 9$ dilution, suggesting that this antiserum was selectively killing a subpopulation of normal lymphocytes. In Table II, it is also clear that there is a relationship between the percentage of cells killed by the absorbed antiserum, and the percentage of $\mathrm{T}$ cells present as determined by the ERFC assay. This relationship is strengthened by the finding that when $\mathrm{B}$ cells were partially depleted from a tonsil cell preparation by removal of CRL (Fig. 1, Table II) the percentage of cells killed was increased from 46 to $76 \%$. To define further the cell subpopulation affected by the antiserum, a combined assay was carried out on normal lymphocytes from peripheral blood and tonsil by testing cells for ERFC before and after cytotoxic treatment. The killing was performed as routinely, then cells from each antiserum dilution were simultaneously examined for ERFC and viability. The percentage

TABLE I

Cytotoxic Activity of RhaNS

\begin{tabular}{lccccc}
\hline & \multicolumn{2}{c}{ Unabsorbed } & & \multicolumn{2}{c}{ Absorbed with Bj cells } \\
\cline { 2 - 3 } \multicolumn{1}{c}{ Lymphocytes } & $\begin{array}{c}\text { Maximum \% } \\
\text { killed cells }\end{array}$ & $\begin{array}{c}50 \% \text { killing } \\
\text { titer }\end{array}$ & & $\begin{array}{c}\text { Maximum \% } \\
\text { killed cells }\end{array}$ & $\begin{array}{c}50 \% \text { killing } \\
\text { titer }\end{array}$ \\
\hline Bj cells & 100 & $350^{*}$ & & 0 & 0 \\
Other cultured cells (3) $\ddagger$ & 100 & 370 & & 100 & 95 \\
Normal blood (3) & 100 & 78 & & 100 & 34 \\
Chronic leukemia & 100 & 50 & 100 & 20 \\
\hline
\end{tabular}

* Reciprocal of antiserum dilution which resulted in $50 \%$ killing.

$\ddagger$ Average of three different samples. 
TABLE II

Cytotoxic Activity of RhaNS after Absorption with B-Cell Lines

\begin{tabular}{lccc}
\hline & \multicolumn{2}{c}{ Maximum \% of cells killed } & \\
\cline { 2 - 4 } \multicolumn{1}{c}{ Cell source } & $\begin{array}{c}\text { Unabsorbed } \\
\text { antiserum }\end{array}$ & $\begin{array}{c}\text { Antiserum absorbed } \\
\text { with five B-cell lines }\end{array}$ & T cell \\
\hline & & & $\%$ of $E R F C$ \\
Absorbing B-cell lines (5)* & 100 & 0 & 0 \\
Other B-cell lines & 100 & 0 & 0 \\
CLL (3) & 100 & 0 & $1-5 \ddagger$ \\
Normal blood (5) & 100 & $60-80 \ddagger$ & $60-75 \ddagger$ \\
Tonsil & 100 & 46 & 50 \\
Tonsil, depleted of CRL & 100 & 76 & 85 \\
\hline
\end{tabular}

* Number of samples per group.

$\ddagger$ Range of individual determinations.

of live cells and the number of live lymphocytes forming $E$ (sheep erythrocyte) rosettes were established by differential counting with a light microscope in the presence of trypan blue. Among peripheral blood lymphocytes the percentage of ERFC before treatment was $70 \%$. This fell to $25 \%$ after treatment with antiserum. Tonsil cells contained $50 \%$ ERFC before treatment and $9 \%$ after treatment. These data indicate that although $\mathrm{T}$ cells were selectively killed by this antiserum, there were some $\mathrm{T}$ cells that were not. Moreover, since antiserum treatment killed $70 \%$ of a cell preparation containing $70 \%$ ERFC, the presence of $25 \%$ ERFC among the surviving cells suggests that this antiserum had some activity against a small proportion of non-ERFC. In the absence of complement, this antiserum had no inhibitory effect on E-rosette formation. It was not possible to define precisely the activity of RhaNS against nonERFC, using B-cell markers, since our fluoresceinated rabbit antihuman gamma globulin cross-reacted with rhesus gamma globulin, and also inhibited EAC-rosette formation (42).

Cultured B-lymphoblast cells. From the absorption studies done on RhaNS there were indications that cultured B cells were antigenically different from normal and CLL lymphocytes. These differences were first established by the inability of $\mathrm{Bj}$ cells to absorb all the reactivity of RhaNS against normal $B$ lymphocytes, other B cell-lines, and CLL cells (Table I). The fact that a pool of five B-cell lines were needed to absorb most of the B-associated antibodies of RhaNS suggested that cultured B cells do not carry all of the antigens present on normal B cells, and that heterogeneity exists among different cultured B-cell lines. To study this aspect in more detail, RhaNS was absorbed with the B-cell line Mo. After absorption of the undiluted serum with $0.7 \times 10^{\circ}$ Mo-cultured cells $/ \mathrm{ml}$, no reactivity was found against the absorbing cells, whereas $100 \%$ of fresh normal lymphocytes collected from the peripheral blood of the same individual, Mo, still reacted. These data indicate that Mo-cultured B cells were unable to absorb out antibodies reactive with Mo normal lymphocytes and suggest that Mo lymphocytes after long-term culture had lost some of their antigenic determinants.

To determine whether or not CLL and B-cultured cells shared antigens not present on normal lymphocytes, rhesus antichronic lymphatic leukemia serum (RhaCLL) and rhesus anticultured B-lymphoid cell serum (RhaBCL) were absorbed with normal lymphocytes. As shown in Table III, RhaBCL, after absorption
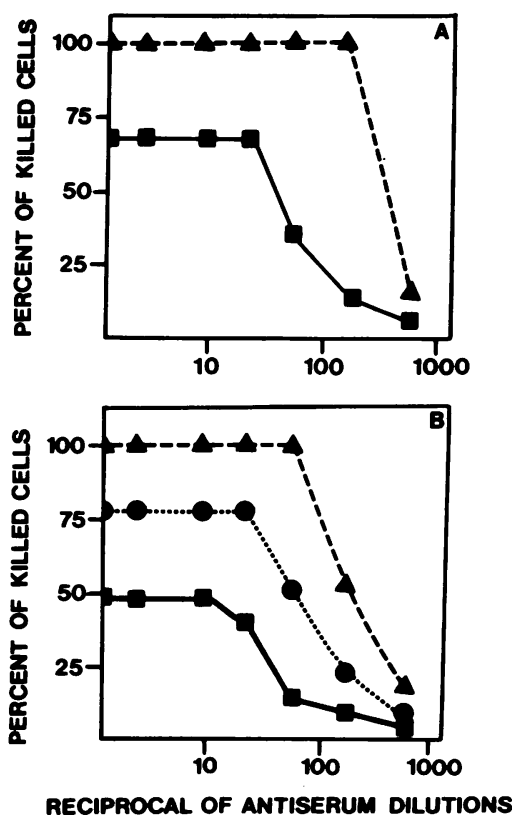

Figure 1 Percentage of peripheral blood lymphocytes (A) and tonsil lymphocytes (B) killed by RhaNS; unabsorbed antiserum (---), and after absorption with cells from five B-cell lines (-), percentage of CRL-depleted tonsil cells killed by absorbed antiserum $(\cdots)$. 
TABLE III

Cytotoxic Activity of RhaBCL (Ib)

\begin{tabular}{lllc}
\hline \multicolumn{1}{c}{ Lymphocytes } & Subjects & $\begin{array}{c}\text { Unabsorbed } \\
\text { antiserum }\end{array}$ & $\begin{array}{c}\text { Antiserum absorbed } \\
\text { with normal spleen }\end{array}$ \\
\hline Normal peripheral blood & $(5)^{*}$ & $100 \pm(3,400)$ & 0 \\
Thoracic duct & $(2)$ & $100(2,400)$ & 0 \\
Chronic leukemia & $(\mathrm{Me})$ & $100(2,750)$ & 0 \\
& $(\mathrm{Ha})$ & $100(2,200)$ & 0 \\
Cultured B cells & $(\mathrm{Ib})$ & $100(1,150)$ & $100(20)$ \\
& $(\mathrm{Mo})$ & $100(1,050)$ & $100(23)$ \\
& $(\mathrm{Bo})$ & $100(900)$ & $80(8)$ \\
\hline
\end{tabular}

* Number of individuals studied.

¥ Percent of maximum killing.

Reciprocal of antiserum dilution required for $50 \%$ killing.

with normal lymphocytes, did not show any reactivity against any CLL cells. Thus, all reactivity of RhaBCL against CLL cells was also associated with normal lymphocytes. Similarly all of the RhaCLL activity against B-cultured cells was absorbed by tonsil lymphocytes (Table IV). Therefore, CLL cells do not appear to contain the unique antigens associated with cultured B cells which are not present on normal lymphocytes or vice versa. Moreover, the antiserum RhaCLL after absorption with one individual's CLL cells had activity directed against other CLL cells, with no detectable activity for any of the cultured B cells tested, as will be discussed below (Table V).

RhaBCL. This antiserum against leukemic cells was produced in a rhesus monkey (RhaCLL) by injecting peripheral blood lymphocytes from CLL patient $(\mathrm{Me})$, over $90 \%$ of which bore B-cell markers. The cytotoxic titers of RhaCLL ranged between $1: 350$ and $1: 8,000$ against leukemic lymphocytes, and had a mean of 1:1,600 against normal lymphocytes. To determine whether this antiserum could discriminate leukemic cells from normal lymphocytes, experiments were performed to study the reactivity of RhaCLL after absorption with normal lymphocytes. Several absorptions with $3.4 \times 10^{\circ}$ tonsil cells $/ \mathrm{ml}$ of serum, were needed to remove all of the cytotoxic reactivity against normal lymphocytes. The absorbing cells represented a pool obtained from 10 individuals and possessed most of the common HL-A antigens. Table IV shows that $75-80 \%$ of the leukemic cells from two CLL patients tested were still killed by the absorbed antiserum, whereas the absorbed antiserum had no effect on the normal or cultured B lymphocytes reacted. These results indicate that $\mathrm{RhaCLL}$ absorbed with tonsil is able to recognize differences between CLL and normal lymphocytes. A second approach was used to study further the specificity of RhaCLL. RhaCLL was absorbed with $2.4 \times 10^{\circ}$ peripheral blood lymphocytes $/ \mathrm{ml}$ of serum from another CLL patient (Ste). This absorption effectively removed cytotoxic activity against eight normal lymphocyte samples, cells from three malignant lymphoproliferative disorders, three cultured lymphoblastoid cell lines, and two cord blood lymphocyte samples (Table V). However, activity remained against 12 CLL preparations. This activity was not related to the HL-A system, since normal cells with similar HL-A profiles to some of the CLL cells tested did not react. Further absorptions with cells from another CLL patient ( $\mathrm{Cia}$ ) were carried out on RhaCLL. This antiserum revealed obvious heterogeneity among CLL cells, since this antiserum still reacted with 4 of 12 CLL tested. The possibility was considered that some of the activity in these absorbed antisera was due to anti-IgM or anti-IgD antibodies, since the immunizing cells were known to carry these Ig classes. Although no antibody with such specificity was detected by immunodiffusion, soluble absorptions were carried out with purified IgM and IgD myeloma proteins. No loss of cytotoxic activity was observed after these absorptions.

Immunofluorescence. Simultaneous studies were performed with rhesus antilymphocyte sera by cytotoxicity and by immunofluorescence. When an antiserum which showed $100 \%$ cytotoxic reactivity was tested by immunofluorescence, $100 \%$ of the cells were strongly stained. Similarly, if an absorbed antiserum with no cytotoxic activity against the absorbing cells was assayed by fluorescence, faint or negative staining was seen. However, when an antiserum such as RhaNS (Table II) which showed partial cytotoxic activity against a given population of cells (65-80\% normal peripheral blood) was studied, no correlation could be found with the extent of fluorescent staining since a higher proportion of cells were stained. Similar findings were seen in comparable studies done on CLL cells with RhaCLL absorbed with Ste cells (Table V).

\section{DISCUSSION}

Although there are numerous communications describing specific antimouse $\mathrm{T}$ - and $\mathrm{B}$-cell antisera, there have been only a few studies reporting similar reagents for human

TABLE IV

Cytotoxic Activity of RhaCLL

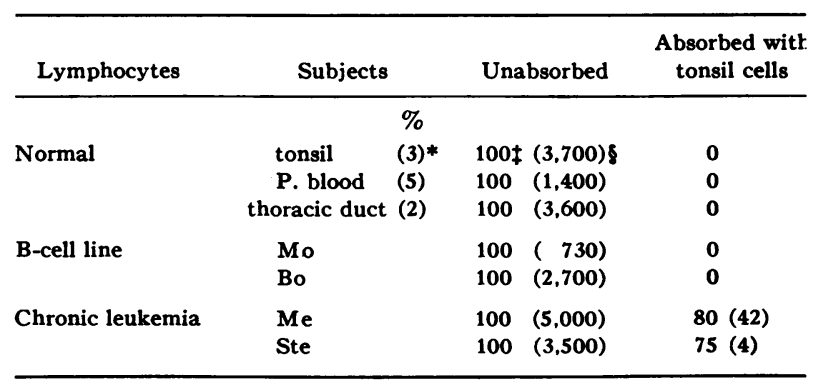

* Number of individuals studied.

‡ Percent of maximum killing.

Reciprocal of antiserum dilution required for $50 \%$ killing. 
TABLE V

Cytotoxic Activity of RhaCLL (Me)

\begin{tabular}{|c|c|c|c|c|}
\hline \multirow[b]{2}{*}{ Lymphocytes } & \multirow[b]{2}{*}{ Subjects } & \multicolumn{3}{|c|}{$50 \%$ killing titer* } \\
\hline & & Unabsorbed & $\begin{array}{c}\text { Absorbed with CLL } \\
\text { Ste }\end{array}$ & $\begin{array}{l}\text { Absorbed with CLL } \\
\text { Ste and Cia }\end{array}$ \\
\hline \multirow[t]{12}{*}{ Chronic leukemia } & $\mathrm{Me}$ & 8,000 & 250 & 200 \\
\hline & Ste & 7,400 & 0 & 0 \\
\hline & $\mathrm{Cia}$ & 4,700 & 45 & 0 \\
\hline & $\mathrm{Ju}$ & 4,000 & 1 & 0 \\
\hline & $\mathrm{Hu}$ & 1,450 & 17 & 0 \\
\hline & $\mathrm{Cu}$ & 520 & 27 & 0 \\
\hline & $\mathrm{He}$ & 300 & 13 & $\mathbf{0}$ \\
\hline & $\mathbf{M a}$ & 6,800 & 150 & 0 \\
\hline & An & 1,400 & 1 & 0 \\
\hline & $\mathrm{Sh}$ & 1,300 & 35 & 6 \\
\hline & $\mathrm{Ve}$ & 1,180 & 45 & 5 \\
\hline & Vo & 520 & 66 & 52 \\
\hline \multirow[t]{2}{*}{ Acute leukemia } & Jo & 3,000 & 0 & \\
\hline & Sto & 1,200 & $\mathbf{0}$ & \\
\hline Lymphosarcoma & Gi & 1,200 & 0 & \\
\hline Normal peripheral blood (7) $\ddagger$ & & 1,600 & $\mathbf{0}$ & \\
\hline Thoracic duct (1) & & 3,700 & 0 & \\
\hline Cord blood (2) & & 575 & $\mathbf{0}$ & \\
\hline B-cell line (3) & & 500 & $\mathbf{0}$ & \\
\hline
\end{tabular}

* Reciprocal of antiserum dilution.

$\ddagger$ Number of individuals studied.

cells. The major obstacles to the production of specific anti-B and anti-T antisera in man, have been attributed to the complexity of the antigenic structure of human lymphocytes and the unpredictable response to antigens specifically associated with either population. Thus, the selection of immunogens, responder animals, immunization schedules, methods for absorption, and criteria of specificity may be critical for the preparation and evaluation of these reagents. Optimal immunization methods have not yet been established.

In our studies we chose rhesus monkeys as responding animals, in the expectation that they would offer the best possibility of producing antibodies directed against minor antigenic differences that might be present on human lymphocyte subpopulations. Indeed some evidence was obtained from our experiments that rhesus anti-CLL serum contained antibodies specifically reactive with minor determinants, against which similarly prepared rabbit antisera had no activity. For instance, the detection of C3d receptors (borne by the immunizing cells) was specifically inhibited by the rhesus antiserum and not by the rabbit antiserum (42). Furthermore, rhesus antispleen serum had inhibitory activity against both $\mathrm{C} 3 \mathrm{~b}$ and C3d receptors (present on splenocytes), whereas analogous antisera raised in rabbits did not.
To analyze our antisera we used the cytotoxicity and immunofluorescence techniques, both of which have been shown to be sensitive and reliable for studying cellmembrane antigens. In comparative studies we found that cell populations which showed either 100 or $0 \%$ reactivity with antisera, did so by both methods. However, using cells among which a subpopulation reacted, there was no strict correlation between the population of cells killed and the proportion showing fluorescent staining. A higher proportion of fluorescent-stained cells was seen. This discrepancy can be explained by the differences in the sensitivity of the methods used, by the nature of the antibodies (some antibodies not complement fixing), or by the binding of Ig molecules to cell membranes other than through the Fab region (i.e., Fc receptor). This disagreement has already been postulated by other authors (41).

In our attempts to obtain an antiserum specific for human $\mathrm{T}$ cells, RhaNS was absorbed with five lymphoblastoid cell lines. After absorption, the antiserum showed reactivity for a subpopulation of normal lymphocytes constituting $60-75 \%$ of peripheral blood lymphoid cells. The proportion of cells with which the serum reacted correlated well with the proportion of ERFC detected in the same preparation. However, when cells 
were tested for ERFC after cytotoxicity treatment, a significant proportion of viable ERFC remained. The facts that the antiserum had no inhibitory activity against the formation of $\mathrm{E}$ rosettes, and nonviable cells failed to form $\mathrm{E}$ rosettes (39) made this combined assay a reliable test. We conclude, therefore, that this absorbed antiserum had cytotoxic activity against a subset of ERFC which represent approximately $75-95 \%$ of the peripheral T-cell population. Since the proportion of lymphocytes killed by the antiserum cannot be attributed entirely to the ERFC population, it can be concluded that the serum was also active against a small subpopulation of non-ERFC. These studies suggest antigenic heterogeneity within the $T$-cell population detected by the E-rosette assay and furthermore suggest the presence of shared antigens between ERFC and a subpopulation of non-ERFC.

Other evidence of antigenic heterogeneity was obtained from studies of CLL-cell and B-cell lines. Cultured lymphoblastoid cells carry membrane receptors present on normal B cells, and it has been thought that their antigenic mosaic may be close to that on normal $B$ lymphocytes, For this reason B-cell lines have been used as absorbents in the preparation of specific anti- $T$ sera. Our findings indicate that such cultured cells are antigenically distinguishable from normal cells, and apparently lack some normal B-cell antigens. Moreover, they show antigenic heterogeneity, as demonstrated by our studies with RhaNS and RhaBCL. It is not possible to assess at this point, whether this heterogeneity is unique to the B-cell line or whether it represents antigenic heterogeneity also present on small subpopulations of normal B lymphocytes.

We confirm previous reports (33) of the ability of monkeys to raise antibodies against antigens associated with CLL cells and not detectable on normal cells ( $\mathrm{Ta}$ ble IV). CLL cells from different patients showed variable reactivity with the antisera. After absorptions with cells from the two most reactive patients (Table V), we found that the differences in cell reactivity were probably due to a major antigenic heterogeneity of CLL cells. The nature of these CLL-associated antigens is difficult to define. They may represent antigens associated with an expanded subpopulation of normal lymphocytes which are present but not detectable by means of our techniques. This argument follows to some extent the rationalization applied to the antigenic definition of myeloma proteins. However, the alternate possibility remains that these are true leukemia-associated determinants, which themselves might reflect dedifferentiation or other intrinsic changes specifically associated with the neoplastic process, such as the appearance of virus induced neo-antigens. Further studies of these leukemiaantigens and of the antigenic heterogeneity of cells from different lymphoproliferative diseases, may provide useful insights into lymphocyte antigenic structure.

\section{ACKNOWLEDGMENTS}

The authors wish to thank Mrs. Fern Ashbough for providing the human material.

This work was supported by: U. S. Public Health Service grant CA 15895, A 109758, and AI 10398, and National Institutes of Health grant RR00163.

\section{REFERENCES}

1. Greaves, M. F., J. J. T. Owen, and M. D. Raff. 1974. $T$ and $B$ lymphocytes origins, properties and roles in immune responses. Excerpta Medica, Amsterdam; and American Elsevier Publishing Co., Inc., New York.

2. Raff, M. C., M. Sternberg, and R. B. Taylor. 1970. Immunoglobulin determinants on the surface of mouse lymphoid cells. Nature (Lond.). 225: 553-554.

3. Rabellino, E., S. Colon, H. M. Grey, and E. R. Unanue. 1971. Immunoglobulins on the surface of lymphocytes. I. Distribution and quantitation. J. Exp. Med. 133: 156167.

4. Grey, H. M., E. Rabellino, and B.Pirofsky. 1971. Immunoglobulins on the surface of lymphocytes. IV. Distribution in hypogammaglobulinemia, cellular immune deficiency, and chronic lymphatic leukemia. J. Clin. Invest. 50: 2368-2375.

5. Bianco, C., R. Patrick, and V. Nussenzweig. 1970. A population of lymphocytes bearing a membrane receptor for antigen-antibody-complement complexes. I. Separation and characterization. J. Exp. Med. 132: 702-720.

6. Dukor, P., C. Bianco, and V. Nussenweig. 1971. Bone marrow origin of complement-receptor lymphocytes. Eur. J. Immunol. 1 : 491-494.

7. Basten, A., J. F. A. P. Miller, J. Sprent, and J. Pye. 1972. A receptor for antibody on B lymphocytes. I. Methods of detection and functional significance. J. Exp. Med. 135 : 610-626.

8. Dickler, H. B., and H. G. Kunkel. 1972. Interaction of aggregated $\gamma$-globulin with B lymphocytes. J. Exp. Med. 136: 191-196.

9. Aoki, T., U. Hämmerling, E. deHarven, E. A. Boyse, and L. J. Old. 1969. Antigenic structure of cell surfaces. An immunoferritin study of the occurrence and topography of $\mathrm{H}-2^{\prime} \theta$, and TL alloantigens on mouse cells. J. Exp. Med. 130: 979-1001.

10. Bron, C., and D. Sauser. 1973. Heterologous antiserum to mouse thymus-derived lymphocytes. J. Immunol. 110: 384-389.

11. Raff, M. G., S. Nase, and N. A. Mitchison. 1971. Mouse specific bone marrow-derived lymphocyte antigen as a marker for thymus-independent lymphocytes. Nature (Lond.). 230: 50-51.

12. Lobo, P. I., F. B. Westervelt, and D. A. Horwitz. 1975. Identification of two populations of immunoglobulinbearing lymphocytes in man. J. Immunol. 114: 116-119.

13. Winchester, R. J., S. M. Fu, T. Hoffman, and H. G. Kunkel. 1975. IgG on lymphocytes surfaces; technical problems and the significance of a third cell population. J. Immunol. 114: 1210-1212.

14. Kurnick, J. T., and H. M. Grey. 1975. Relationship between immunoglobulin-bearing lymphocytes and cells reactive with sensitized human erythrocytes. J. Immunol. 115: 305-307. 
15. Anderson, C. L., and H. M. Grey. 1974. Receptors for aggregated IgG on mouse lymphocytes. Their presence on thymocytes, thymus-derived, and bone marrow-derived lymphocytes. J. Exp. Med. 139: 1175-1188.

16. Niederhuber, J. E., S. Britton, and R. Berquist. 1972. A specific mouse $B$ lymphocyte antigen (MBLA) demonstrated by double immunofluorescence. J. Immunol. 109: 366-370.

17. Golub, E. S. 1971. Brain-associated $\theta$ antigen: reactivity of rabbit anti-mouse brain with mouse lymphoid cells. Cell. Immunol. 2: 353-361.

18. Fradelizi, D. P., C. T. Chou, B. Cinader, and S. Dubisky. 1973. A membrane antigen of rabbit thymus cells Cell Immunol. 7 : 484-501.

19. Toben, H. R., and M. D. Cooper. 1972. Preparation of cytotoxic antisera with specificity for human $\mathrm{T}$ lymphocytes. Clin. Res. 20: 797. (Abstr.)

20. Williams, R. C., Jr., J. R. DeBoard, O. J. Mellbye, R. P. Messner, and F. D. Linström. 1973. Studies of $\mathrm{T}$ - and B-lymphocytes in patients with connective tissue diseases. J. Clin. Invest. 52: 283-295.

21. Smith, R. W., W. D. Terry, D. N. Buell, and K. W. Sell. 1973. An antigenic marker for human thymic lymphocytes. J. Immunol. 110: 884-887.

22. Brown, G., and M. F. Greaves. 1974. Cell surface markers for human $\mathrm{T}$ and $\mathrm{B}$ lymphocytes. Eur. J. Immunol. 4 : 302-310.

23. Aiuti, F., and H. Wigzell. 1973. Function and distribution pattern of human $\mathrm{T}$ lymphocytes. II. Presence of $T$ lymphocytes in normal humans and in humans with various immunodeficiency disorders. Clin. Exp. Immunol. 13: 183-189.

24. Greaves, M. F., and G. Brown. 1973. A human B lymphocyte specific antigen. Nat. New Biol. 246: 116-119.

25. Greenspan, I., E. R. Brown, and S. O. Schwartz. 1963. Immunologically specific antigens in leukemic tissues. Blood. 21 : 717-728.

26. Fink, M. A., R. A. Malmgren, F. J. Rauscher, H. C. Orr, and M. Karon. 1964. Application of immunofluorescence to the study of human leukemia. J. Natl. Cancer Inst. 33: 581-588.

27. Fink, M. A., M. Karon, F. J. Rauscher, R. A. Malmgren, and H. C. Orr. 1965. Further observations on the immunofluorescence of cells in human leukemia. Cancer. 18: $1317-1321$.

28. Tanigaki, N., Y. Yagi, G. E. Moore, and D. Pressman. 1967. Antibodies against human leukemia cell lines. $J$. Immunol. 98 : 281-292.

29. Hyde, R. M., S. Garb, and A. J. Bennett. 1967. Demonstration by immunoelectrophoresis of antigen in human myelogeneous leukemia. J. Natl. Cancer Inst. 38: 909-919.
30. Bates, H. A., R. O. Bankole, and W. R. Swaim. 1969. Immunofluorescent studies in human leukemia. Blood. $34: 430-440$.

31. Yata, J., G. Klein, N. Kobayashi, T. Furukawa, and M. Yanagisawa. 1970. Human thymus-lymphoid tissue antigen and its presence in laeukemia and lymphoma. Clin. Exp. Immunol. 7: 781-792.

32. Bentwich, Z., D. W. Weiss, D. Sulitzeanu, E. Kedar, G. Izak, I. Cohen, and O. Eyal. 1972. Antigenic changes on the surface of lymphocytes from patients with chronic lymphocytic leuktemia. Cancer Res. 32: 1375-1383.

33. Metzgar, R. S., T. Mohanakumar, and D. S. Miller. 1972. Antigens specific for human lymphocytic and myeloid leukemia cells: Detection by nonhuman primate antiserums. Science (Wash. D. C.). 178: 986-988.

34. Bias, W. B., G. W. Santos, P. J. Burke, G. M. Mullins, and R. L. Humphrey. 1972. Cytotoxic antibody in normal human serums reactive with tumor cells from acute lymphocytic leukemia. Science (Wash. D. C.). 178: 304-306.

35. Litwin, S. D., T. H. Hütterroth, P. K. Lin, J. Kennard, and $H$. Cleve. 1974. Immunoglobulin expression of cells from human lymphoblastoid lines. I. Heavy and light chain antigens of the cell surface. J. Immunol. 113: 661-667.

36. Lerner, R. A., P. J. McConahey, I. Jansen, and F. J. Dixon. 1972. Synthesis of plasma membrane-associated and secretory immunoglobulin in diploid lymprocytes. $J$. Exp. Med. 135: 136-149.

37. Wigzell, H. 1965. Quantitative titrations of mouse H-2 antibodies using $\mathrm{Cr}^{5}$-labelled target cells. Transplantation. (Baltimore). 3 : 423-431.

38. Spiegelberg, H. L., and W. O. Weigle. 1968. The production of antisera to human $\gamma \mathrm{G}$ subclasses in rabbits using immunological unresponsiveness. J. Immunol. 101: 377-380.

39. Ross, G. D., E. M. Rabellino, M. J. Polley, and H. M. Grey. 1973. Combined studies of complement receptor and surface immunoglobulin-bearing cells and sheep erythrocyte rosette-forming cells in normal and leukemic human lymphocytes. J. Clin. Invest. 52: 377-385.

40. Fröland, S. S. 1972. Binding of sheep erythrocytes to human lymphocytes. A probable marker of $\mathrm{T}$ lymphocytes. Scand. J. Immunol. 1: 269-280.

41. Identification, enumeration and isolation of $B$ and $T$ lymphocytes from human peripheral blood. 1974. Report of a WHO/IARC-Sponsored Workshop on Human B and T cells, London, 15-17 July, 1974. Scand. J. Immunol. 3 : 521-532.

42. Ross, G. D., M. J. Polley, E. M. Rabellino, and H. M. Grey. 1973. Two different complement receptors on human lymphocytes. One specific for $\mathrm{C} 3 \mathrm{~b}$ and one specific for C3b inactivator-cleared C3b. 